\title{
Ergonomic Risk-prone Activities toward Nurses in the Intensive Care and Emergency Room
}

\author{
Dewi Sartika $^{1 *(\mathbb{D})}$, Elly Nurrachmah ${ }^{2}$, Dewi Irawaty Sukirman ${ }^{3}$ (i) Muchtaruddin Mansyur $^{4} \mathbb{D}$, Basuki Supartono ${ }^{5}$ (i) \\ ${ }^{1}$ Nursing Program, Health Polytechnic of Riau, Pekanbaru, Indonesia; ${ }^{2}$ Department of Medical Surgery, Faculty of Nursing, University \\ of Indonesia, Jakarta, Indonesia; ${ }^{3}$ Department of Basic Science and Fundamentals of Nursing, Faculty of Nursing, University \\ of Indonesia, Jakarta, Indonesia; ${ }^{4}$ Department of Community Medicine, Faculty of Medicine, University of Indonesia, Jakarta, \\ Indonesia; ${ }^{5}$ Medical Professional Study Program, Faculty of Medicine, Pembangunan Nasional University, Jakarta, Indonesia
}

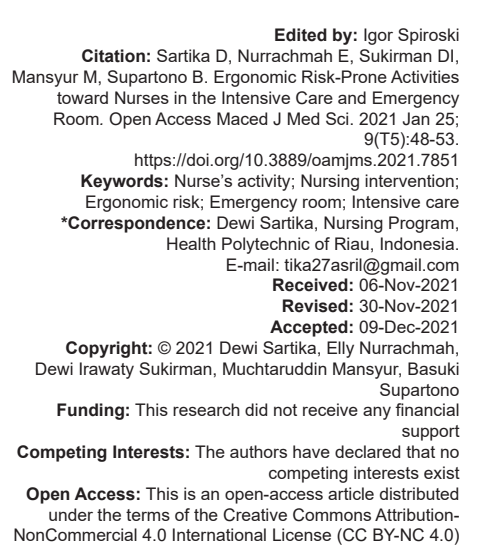

Introduction

Nurses are the largest workforce who have a unique role in achieving health goals for the entire community through the provision of nursing care. In carrying out various activities, nurses have the risk of ergonomic hazards in providing nursing care, especially with increasingly dynamic health services such as during Coronavirus disease-19 pandemic like today. Nurses in intensive care units (ICU) have the highest ergonomic risk and are more likely to have symptoms of musculoskeletal system disorders to musculoskeletal injuries. The results of several studies indicated that there are activities that have ergonomic risks in the ICU [1], [2]. These activities are changing the patient's position, transferring the patient, suctioning, calculating fluid balance, and documenting the patient's hemodynamic results [3], [4], [5], [6].

In addition to the intensive care room or unit, the results of several studies also showed that routine activities in the Emergency Room (ER) have ergonomic risks. These activities are the installation of Electro Kardio Gram (EKG), measurement of vital signs, infusion, hecting, taking patient blood samples, as well as lifting and transferring the patients [7], [8], [9], [10], [11], [12].

Ergonomic hazards in the long-term will have impacts on health [13]. The results of research by Azma et al. stated that there were $88.6 \%$ of nurses at the General Hospital in Klang Valley Malaysia had experienced suffering from musculoskeletal disorders [14]. Several studies have shown that a more specific health impact, namely, Low Back Pain (LBP), has been shown. Budhrani-Shani et al. (2016) stated that LBP incidence in nurses worldwide was 50-80\% [15]. Furthermore, the American Nurses Association survey showed that the number of back pain in nurses continues to increase every year [16], [17]. Research in several countries, such as by Al-Samawi and Awad (2015) in Sudan showed the frequency of LBP in nurses was $87.5 \%$ [18], 85.9\% in Slovenia [19], $65 \%$ in Nepal (Rustoen, 2016), and 72\% in Taiwan [20]. Another study by Sumangando et al. (2017) at a hospital in Manado, Indonesia, showed $70 \%$ of nurses experienced LBP [21]. In addition, the research by Ningsih (2017) at a hospital in Pangkalan Kerinci, Indonesia, showed $43.4 \%$ of nurses experienced LBP [22]. 
Complaints to the musculoskeletal system do not occur directly, but complaints will arise after a long [23], [1]. LBP is one of the most frequently complained by nurses, which can negatively impact if prevention is not done [24], [25], [26]. These adverse effects include fatigue, increased leave and illness, disability, reduced quality of life, productivity and performance of nurses, decreased job satisfaction, influenced decisions to quit as nurses, and increased health costs [27], [28], [29], [30], [31], [32].

Based on the Regulation of the Health Ministry of the Republic of Indonesia number 66 (2016) concerning occupational health and safety in hospitals, the regulation of hospital occupational health and safety is carried out for the implementation of occupational health and safety in hospitals in an optimal, effective, efficient, and sustainable manner. This approach aims to prevent accidents and injuries and maintain safe conditions for hospital resources, patients, patient companions, and visitors. This is done through risk identification and assessment, risk mapping area, and control efforts.

A preliminary study in a hospital in Pekanbaru City, Riau, showed that the most common potential hazard experienced by nurses in the past year was ergonomic hazard which had an impact on LBP complaints by $73 \%$. Furthermore, the most LBP complaints were experienced by nurses in the intensive care room and ER. Based on this preliminary study, information was also obtained that LBP complaints had an impact on increasing the absenteeism of executive nurses and disrupting nursing services. The results of field observations also showed that the work attitude of the nurses is not in accordance with the ergonomic principles.

The application of ergonomic principles in the workplace is still not a priority for nurses while working in hospitals. As a first step, efforts to identify and assess the risks of nursing activities need to be carried out. Therefore, researchers were interested in evaluating the ergonomic risks of the activities carried out in implementing nursing care by nurses in the intensive care and ER, a hospital in Riau, Indonesia.

\section{Methods}

This study is conducted by observing routine activities with a similar task group technique, namely, identifying ergonomic risks in groups that have the same job. This study based on the group of nursing care carried out by nurses in the intensive care and the ER of a hospital in Riau.

The instrument used was the Rapid Entire Body Assessment (REBA) observation sheet. REBA is a method of assessing ergonomic risk in the workplace that is used quickly to assess the posture of a worker's neck, back, arms, wrists, and legs that focus on repetitive movements and the most frequent movements from head to toe [33], [34]. REBA observation sheet is a standard instrument and has been widely used in various studies to assess ergonomic risks in an activity from work. Ergonomic risk assessment using the REBA method was carried out in the following steps: (1) Observing work/activities and the results of job observations were recorded in videos and photos, (2) selecting the posture to be studied, and (3) performing an assessment using the steps on the REBA analysis sheet. REBA observation sheet can be seen in Figure 1 below.

The observed activities were obtained from 17 nurses from the intensive care room and ten nurses in the ER. There were six activities observed in the intensive care room. These activities are bathing the patients, transferring the patient, wounds dressing, taking blood samples for AGDA examination, installing infusions, and installing an EKG, while in the ER, there are two activities, namely, transferring the patient and installing infusions.

This research has applied the principles of research ethics by obtaining the approval of the research protocol from the Ethics Committee of the Faculty of Nursing, University of Indonesia. The researchers have also obtained written consent from the participants (informed consent) involved in this study.

\section{Results}

The results of observations on activities that have ergonomic risks in the intensive care and the ER are shown in Table 1 below.

Table 1 shows that the activity with the most ergonomic risks in the intensive care room is bathing the patient with a total score of 13 , while in the ER is transferring the patient with a total score of 12 .

In detail, the results of the REBA analysis for bathing patient are shown in Table 2 below.

Table 2 shows that the REBA total score for bathing the patient is at level 4, indicating that this condition is dangerous, so inspection and changes are needed immediately. The total score was obtained from the sum of the scores of tables $A, B$, and $C$ and activity values based on the duration of the work. The score of table $A$ is the cutoff point of the ergonomic risk assessment for neck, legs, and trunk posture, which amount to ten. The score of table B score is the cutoff point of the ergonomic risk assessment for the lower arms, wrists, and upper arms, which amount to nine. The score of table $C$ is the cutoff point of point of the scores of tables $A$ and $B$, which amount to 12 . 


\section{ERGONAMICSS REBA Employee Assessment Worksheet Task Name: Date}

A. Neck, Trunk and Leg Analysls

Step 1: Locate Neck Position
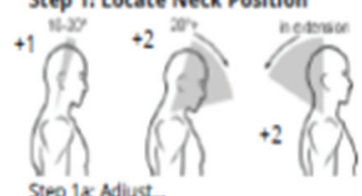

If neck is twisted.

If neck is side bending +1

Step 2: Locate Trunk Position

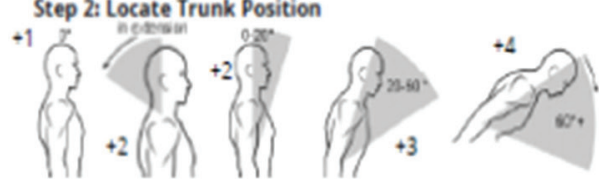

Step 2x: Adjust.

If trunk is twisted + 1

If trunk is side bending +1

Step 3: Legs

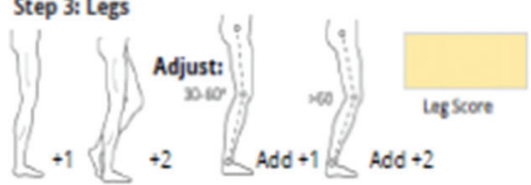

Step 4: Look-up Posture Score in Table A

Using values from steps 1.3 above,

Locate score in Tatie A

Step 5: Add Force/Load Score

If load < 11 bs. : $* 0$

If load 11 to 22 bs: : *1

if load $>22$ bs: +2

Adjust if shock or rapid build up of force. add +1 ferce $/$ Losd score

Step 6: Score A, Find Row in Table C

Add values from steps 4 \& 5 to obcain Score A

And Row in Table $C$.

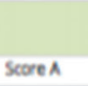

Scoring

$1=$ Negligble Risk

2.3 = Low Risk. Change may be needed.

47 - Medum Risk. Further Investigate. Change Soon.

$8-10$ - High Risk investigate and implement Change

11 * - Very High Risk. Implement Change
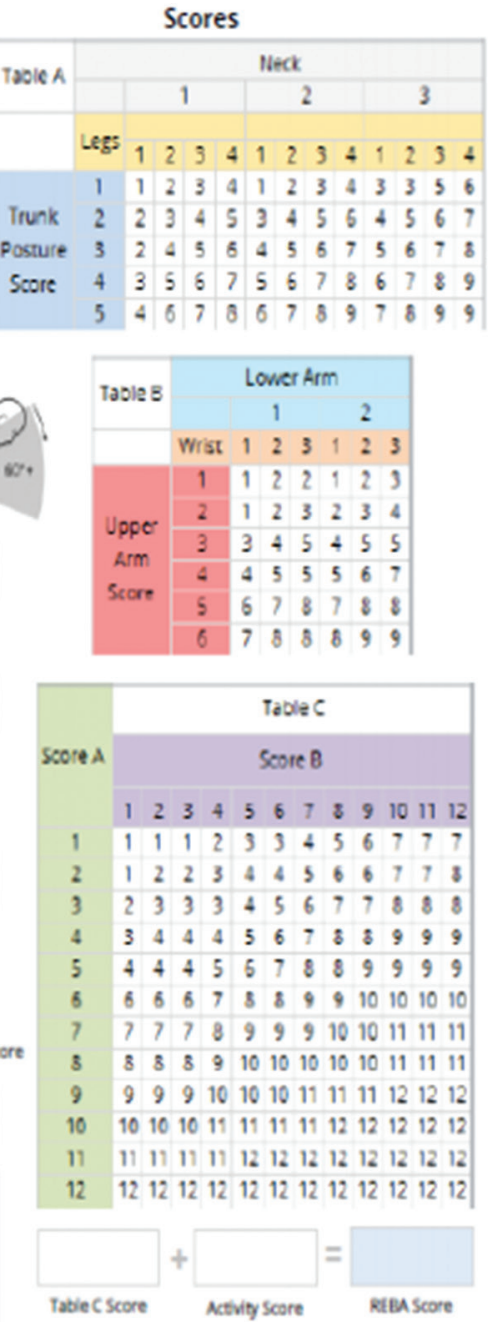

B. Arm and Wrist Analysis

Step 7: Locate Upper Arm Position:

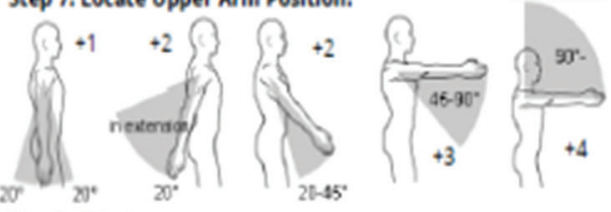

Step 7x: Adlust.

If shoulder is rasect +1

If upper arm is abducted: *?

If arm is supported or person is leaning:-

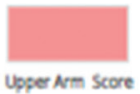

Steo 8: Locate Lower Arm Position:

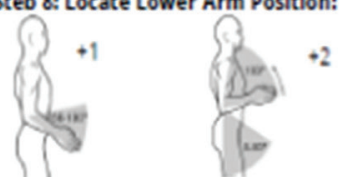

Arm Score

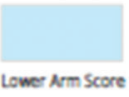

Steo 9: Locate Wrist Position:

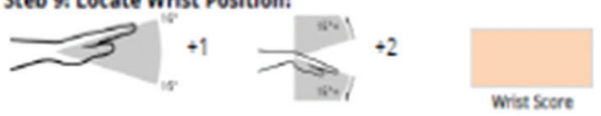

Step 9x: Adjust.

If wrist is bert from midine or twisted: Add +1

Step 10: Look-up Posture Score in Table B

Uaing values from staps 7.9 above, lscate score in fable

Step 11: Add Coupling Score

Wel fitting Handle and mid rang power grip, good: to

Acceptable but not ideal hand hoid or coupling

acceptable with another body part, fair: +1

Hand hold not acceptable but possble, poor: +2

No handles, awkward, unsate with ary body part.

Unacceptable: $t 3$

Step 12: Score B, Find Column in Table C

Add values from steps 10811 to obtain

Score B. Find column in Table C and match with

Score A in fow from step 6 to obtain Table C Score.

Step 13: Activity Score

i1 1 or more body parts are heid for longer than 1 minute (static)

1 Repeated smal range actions (more than $4 x$ per minute)

1 Adtion causes rapid large rarge changes in postures or unstable base

Figure 1: REBA analysis sheet. Source: Ergo-Plus Channel, 2004, page 2

Table 1: Results of observation of activities prone to ergonomic risk in the intensive care and the emergency room

\begin{tabular}{|c|c|c|}
\hline Room & Activities & Score result (using REBA) \\
\hline Intensive & Bathing the patient & Total score: 13 (Action level 4: A score of 11-15 \\
\hline \multirow[t]{8}{*}{ Care } & & $\begin{array}{l}\text { indicates that this condition is dangerous, so } \\
\text { inspection and changes are needed immediately (on } \\
\text { the spot)) }\end{array}$ \\
\hline & Wound dressing & $\begin{array}{l}\text { Total score: } 11 \text { (Action level } 4 \text { : A score of } 11-15 \\
\text { indicates that this condition is dangerous, so inspection } \\
\text { and changes are needed immediately (on the spot)) }\end{array}$ \\
\hline & $\begin{array}{l}\text { Transferring the } \\
\text { patient }\end{array}$ & $\begin{array}{l}\text { Total score: } 10 \text { (Action level } 3 \text { : A score of } 8-10 \\
\text { indicates that an inspection is needed and changes } \\
\text { are needed urgently) }\end{array}$ \\
\hline & $\begin{array}{l}\text { Taking blood } \\
\text { samples for AGDA } \\
\text { examinations }\end{array}$ & $\begin{array}{l}\text { Total score: } 11 \text { (Action level } 4 \text { : A score of } 11-15 \\
\text { indicates that this condition is dangerous so } \\
\text { inspection and changes are needed immediately (on } \\
\text { the spot)) }\end{array}$ \\
\hline & $\begin{array}{l}\text { Inserting the } \\
\text { intravenous needle }\end{array}$ & $\begin{array}{l}\text { Total score: } 5 \text { (Action level 2: A score of } 4-7 \text { indicates } \\
\text { that checks and changes need to be made) }\end{array}$ \\
\hline & Inserting & Total score: 8 (Action level 3: A score of 8-10 \\
\hline & Electrocardiogram & $\begin{array}{l}\text { indicates that an inspection is needed and changes } \\
\text { are needed urgently) }\end{array}$ \\
\hline & $\begin{array}{l}\text { Transferring the } \\
\text { patient }\end{array}$ & $\begin{array}{l}\text { Total score: } 12 \text { (Action level } 4 \text { : A score of } 11-15 \\
\text { indicates that this condition is dangerous so } \\
\text { inspection and changes are needed immediately (on } \\
\text { the spot)) }\end{array}$ \\
\hline ER & $\begin{array}{l}\text { Inserting the } \\
\text { intravenous needle }\end{array}$ & $\begin{array}{l}\text { Total score: } 10 \text { (Action level 3: A score of } 8-10 \\
\text { indicates that an inspection is needed and changes } \\
\text { are needed urgently) }\end{array}$ \\
\hline
\end{tabular}

The activity score was one, which means if the position of one or more of the body parts is longer than $1 \mathrm{~min}$ (static). Hence, the total score was $12+1=13$.

In contrast to activities in the intensive care room, the activities in the ER that has the most ergonomic risk are transferring the patient. The results of the REBA analysis for transferring the patient are shown in Table 3 below.

Table 3 shows that the REBA total score result for transferring the patient is also at level 4 , indicating that this condition is dangerous, so inspection and changes are needed immediately. The score of table $A$ is the cutoff point of the ergonomic risk assessment for neck, legs, and trunk posture, which amount to nine. The score of table B score is the cutoff point of the ergonomic risk assessment for the lower arms, wrists, and upper arms, which amount to nine. The score of table $\mathrm{C}$ is the cutoff point of point of the scores of tables $A$ and $B$, which amount to 11 . The activity score was 
Table 2: Results of the REBA score for patient bathing activities in the intensive care room

\begin{tabular}{|c|c|c|c|}
\hline Score of Table A & Score of Table B & Score of Table C & Total Score \\
\hline & Score of Table $B=9$ & Score of Table $\mathrm{C}=12$ & Total score: \\
\hline 1 (2) 1 & & $+\infty$ & 12 (cutoff point of Table A and B results +1 (activity) $=13$ \\
\hline 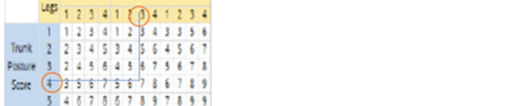 & 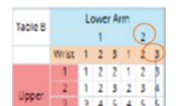 & 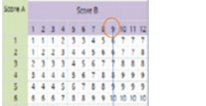 & (Action level 4: A score of 11-15) \\
\hline Score $=$ posture A score + Force/Load Score $\rightarrow 7+3=10$ & 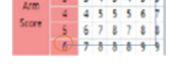 & 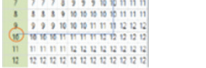 & \\
\hline
\end{tabular}

one, which means if the position of one or more of the body parts is longer than $1 \mathrm{~min}$ (static). Hence, the total score was $11+1=12$.

\section{Discussion}

The result shows that the REBA score for bathing the patient in the intensive care room is at level 4 , indicating that this condition is dangerous, so inspection and changes are needed immediately. Bathing the patient is an independent nursing intervention for nurses in the intensive care room, especially in the ICU, and is part of the nursing intervention to fulfill personal hygiene needs. This activity is carried out routinely every morning in the morning shift, which is preceded by suction, oral hygiene, and wound dressing. At the time of bathing, the patient's position is also adjusted, and after that, the patient's bed linen is changed.

Based on the results of observations that have been made, the length of time for all these activities is approximately $2 \mathrm{~h}$ without rest. The duration of bathing the patient alone takes about $0.5-1 \mathrm{~h}$, depending on the patient's condition, the number of patients and the number of nurses who perform these activities. The dominant working attitude of the nurse when bathing the patient is standing for a long time with the back leaning forward, holding the patient's weight, rotating the body, and occasionally having an awkward posture, especially at the activity node; reaching and cleaning the patient's body parts that are difficult to reach, such as the buttocks and lower back extremities.

One of the ergonomic principles that need to be applied by individuals in their work is a standing position that is not awkward, namely, with a vertical spine position and body weight balanced on two legs [35]. Awkward postures when sitting or standing will increase the workload of the muscles so that the amount of work required is greater, due to the inefficient transfer of energy from the muscles to the skeletal system so that it is easy to cause fatigue [36], [37]. In addition, standing work postures can cause some problems with the musculoskeletal system, such as LBP, especially in the standing working position with the back leaning forward [12].

The riskiest activities in the intensive care room in this study are different from the results of several previous studies. As in the research by Senthilkumar and Gokul (2019), the activity that is considered the riskiest is documenting the hemodynamic results of the patient [6]. In the research done by Meepradit et al. (2018), the activity that is considered the riskiest is transferring the patient [5]. Differences in the results of the riskiest activities found in several studies may occur due to several factors. These factors can come from individuals who carry out the activities, as well as factors from outside the individual such as workload, facilities, available time, and the work environment of the intensive care room at different hospitals.

The result shows that the REBA score result for transferring the patient in the ER is also at level 4, indicating that this condition is dangerous, so inspection and changes are needed immediately. Transferring the patient observed in this study was transferring the patient for X-rays or CT-scans and returning to the ER. The dominant working attitudes of the implementing nurse when doing this activity are pushing, pulling, and holding the load (bed), twisting movements when the road turns, and occasionally having awkward postures. This is exacerbated by the nurses walking to a quite far from the ER location, some roads turn and climb, and sometimes not all the wheels of the bed are functioning properly, thus requiring extra strength to push, pull, and hold the load.

One of the ergonomic principles in work is to reduce the workload. Reducing excessive loads can minimize the force used when working to avoid

Table 3: REBA score result for transferring the patient in the emergency room

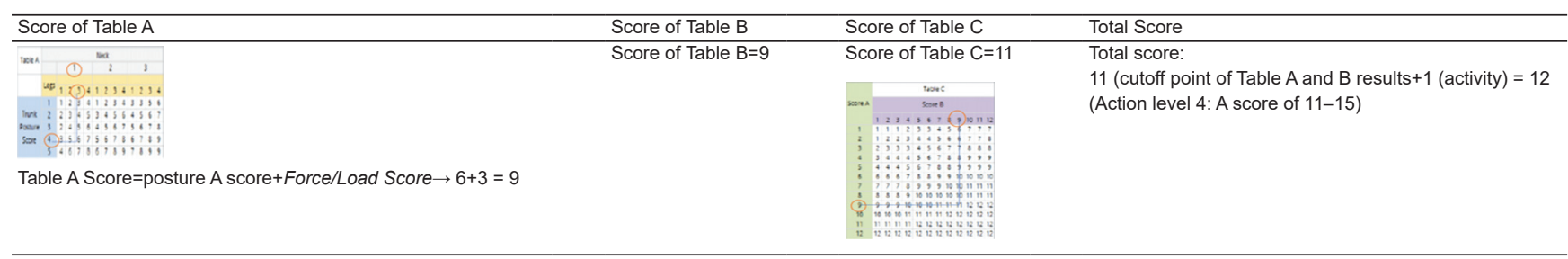


fatigue and work accidents [38], [35]. Heavy loads would cause mechanical loads, irritation, inflammation, muscle fatigue, damage to muscles, tendons, and other tissues [5]. This is supported by the research conducted by Nurwahuni et al. (2012), who reported that the highest percentage of workers who experienced LBP complaints were workers with a weight of more than $25 \mathrm{~kg}$ [39]. The research conducted by Kurniawidjaja et al. (2014) also shows that transferring the patient that is considered the most at risk is also shown. This study proved that transferring the patient has a significant relationship with the level of risk of LBP [9]

The implication of this result is this risky condition needs to be considered by the relevant parties in the hospital to make immediate control. Besides having important findings, the results of this study also have limitations, namely, only assessing risky work postures using REBA instrument, and not paying attention to other factors that may affect them. These factors can be in the form of individual factors of nurses, facilities, and work environment that are also supportive in carrying out activities [40].

\section{Conclusion}

The results showed that the riskiest activities in the two rooms were at level 4, which indicates that this condition is dangerous, so inspection and changes are needed immediately. Other influencing factors such as individual factors, the facilities used, and the work environment also need to be studied further. In addition, the ergonomic approaches that can be suggested to the nurses are regular stretching, risky physical muscle strength exercises, and also improving the posture by applying ergonomic principles while working. These results can also be used as input in developing a specific ergonomic hazard prevention model based on ergonomic risks in nursing interventions that have been identified so that adverse effects on nurses in the future can be prevented.

\section{References}

1. Freimann $T$, Merisalu E, Pääsuke M. Effects of a homeexercise therapy programme on cervical and lumbar range of motion among nurses with neck and lower back pain: A quasiexperimental study. BMC Sports Sci Med Rehabil. 2015;7(1):31. http//doi.org/10.1186/s13102-015-0025-6

PMid:26640694

2. Galletta M, Portoghese I, D'Aloja E, Mereu A, Contu P, Coppola RC, et al. Relationship between job burnout, psychosocial factors and health care-associated infections in critical care units. Intensive Crit Care Nurs. 2016;34,59-66. http//doi.org/10.1016/j.iccn.2015.11.004

PMid:26961918

3. Karahan A, Bayraktar N. Effectiveness of an education program to prevent nurses' low back pain: An interventional study in Turkey. Workplace Health Saf. 2013;61(2):73-8. http://doi. org/10.1177/216507991306100205

PMid:23380640

4. Kozak A, Freitag S, Nienhaus A. Evaluation of a training program to reduce stressful trunk postures in the nursing professions: A pilot study. Ann Work Exp Health. 2017;61(1):22-32. http://doi. org/10.1093/annweh/wxw002

PMid:28395308

5. Meepradit P, Panyadee K, Yingratanasuk T. The effectiveness of the lateral patient transfer device to reduce musculoskeletal risk among practical nurses in a hospital, Thailand. J Biosci Med. 2018;6(5):45-51.

6. Senthilkumar S, Gokul SK. Rapid Upper limb analysis in musculoskeletal disorders among intensive care unit nurses. GROUP. 2019;65(11):24-5.

7. Jellad A, Lajili $H$, Boudokhane $S$, Migaou $H$, Maatallah $S$, Frih ZB. Musculoskeletal disorders among Tunisian hospital staff: Prevalence and risk factors. Egypt Rheumatol. 2013;35(2):59-63.

8. Kadda O, Marvaki C, Panagiotakos D. The role of nursing education after a cardiac event. Health Sci J. 2012;6(4):634-46.

9. Kurniawidjaja LM, Purnomo E, Maretti N, Pujiriani I. Control Ergonomic risks of low back pain cases in nurses at the hospital. Majalah Kedokteran Bandung. 2014;46(4):225-33.

10. Prapti NK, Nurhesti PO, Tirtayasa K. Ergonomic studies on nursing actions at IRD Udayana University Hospital, Badung, Bali. J Keperawatan Respati Yogyakarta. 2018;5(3):414-9.

11. Rogers B, Buckheit K, Ostendorf J. Ergonomics and nursing in hospital environments. Workplace Health Safety. 2013;61(10):429-39. http://doi. org/10.1177/216507991306101003 PMid:24053216

12. Wajdi F, Kusmasari W. Resiko Jenis Pekerjaan Terhadap Keluhan Muskuloskeletal Disorders Pada Perawat Rumah Sakit. Prosiding Semnastek; 2015.

13. International Labour Organization. Kesehatan Kerja Sarana untuk Produktivitas. Jakarta: International Labour Organization; 2013.

14. Azma BA, Rusli BN, Oxley J, Quek K. Work related musculoskeletal disorders in female nursing personnel: Prevalence and impact. Int J Collab Res Intern Med Public Health. 2016;8(3):294-8

15. Budhrani-Shani P, Berry DL, Arcari P, Langevin H, Wayne PM Mind-body exercises for nurses with chronic low back pain: An evidence-based review. Nurs Res Pract. 2016;2016:9018036. http//doi.org/10.1155/2016/9018036 PMid:27446610

16. Newland JA. Year of the healthy nurse. In: The Nurse Practitioner. Vol. 42. United States: Wolter Kluwer Health; 2017. p. 6.

17. Netto E, Hamedon TR. Systematic review on educational interventional studies in reducing work-related injuries among healthcare workers. Int J Public Health Clin Sci. 2018;5(4):1-11.

18. Abedini R, Choobineh AR, Hasanzadeh J. Patient manual handling risk assessment among hospital nurses. Work. 2015;50(4):669-75. http//doi.org/10.3233/WOR-141826 PMid:24448012

19. Skela-Savič B, Pesjak K, Hvalič-Touzery S. Low back pain among nurses in Slovenian hospitals: Cross-sectional study. Int Nurs Rev. 2017;64(4):544-51. http://doi.org/10.1111/inr.12376 


\section{PMid:28444732}

20. Shieh SH, Sung FC, Su CH, Tsai $Y$, Hsieh VC. Increased low back pain risk in nurses with high workload for patient care: A questionnaire survey. Taiwan J Obstet Gynecol. 2016;55(4):525-9. http://doi.org/10.1016/j.tjog.2016.06.013 PMid:27590376

21. Sumangando M, Rottie J, Lolong J. Workload relationship with the incidence of low back pain (LBP) in nurses executor at Grade III RW Monginsidi Hospital Manado. J Keperawatan. 2017;5(1):1-9.

22. Ningsih KW. Complaints of low back pain in inpatient nurses at the Selasih Base Kerinci Hospital. J Ipteks Terapan. 2017;11(1):75-88.

23. Dong H, Zhang Q, Liu G, Shao T, Xu Y. Prevalence and associated factors of musculoskeletal disorders among Chinese healthcare professionals working in tertiary hospitals: A crosssectional study. BMC Musculoskelet Disord. 2019;20(1):175. PMid:31014316

24. Emmanuel NM, Ezhilarasu P, Bheemarao AB. Low back pain among nurses in a tertiary hospital, South India. J Osteoporos Phys Act. 2015;3:4. http//doi.org/10.4172/2329-9509.1000161

25. Health and Safety Executive. Health and Safety Executive Annual Report and Accounts; 2018. Available from: http://www. hse.gov.uk. [Last accessed on 2020 Oct 15].

26. Johnson OE, Edward E. Prevalence and risk factors of low back pain among workers in a health facility in South-South Nigeria. J Adv Med Med Res. 2016;11(8):1-8. http://doi.org/10.9734/ BJMMR/2016/20785

27. Abebe AD, Gebrehiwot EM, Lema S, Abebe TW. Prevalence of low back pain and associated risk factors among Adama Hospital Medical College Staff, Ethiopia. Eur J Prev Med 2015;3(6):188-92.

28. Abou El-Soud AM, El-Najjar AR, El-Fattah NA, Hassan AA. Prevalence of low back pain in working nurses in Zagazig University Hospitals: An epidemiological study. Egypt Rheumatol Rehabil. 2014;41(3):109-15.

29. Al-Samawi MA, Awad HM. Prevalence of low back pain among nurses working in Elmak Nimer University hospital ShendiSudan 2015. Int J Res Granthaalayah 2015;3(9):108-21.
30. Hoy D, March L, Brooks P, Blyth F, Woolf A, Bain C, Buchbinder R. The global burden of low back pain: Estimates from the Global Burden of Disease 2010 study. Ann Rheum Dis. 2014;73(6):968-74. http://doi.org/10.1136/ annrheumdis-2013-204428

\section{PMid:24665116}

31. Tosunoz IK, Oztunc G. Low back pain in nurses. Int J Caring Sci. 2017; 10(3):1728-32.

32. Yitayeh A, Fasika S, Mekonnen S, Gizachew M. Work related musculoskeletal disorders and associated factors among nurses working in governmental health institutions of Gondar town, Ethiopia, 2013. Physiotherapy. 2015;101:e1694. http:// doi.org/10.1016/j.physio.2015.03.102

33. Ergointelligent. Software of Ergonomics; 2011. Available from: http://www.ergointelligent.com. [Last accessed on 2020 Dec 02].

34. Sutrio FO, Oktri M. Analysis of RULa and REBA Measurement Officers in the Lifting of Goods in the Warehouse by Using Ergointelligence Software (Case Study: Goods Carrier Officer at Dewi's Store, Bandung). National Seminar on Applied Research and Technology. Atma Jaya Christian University Faculty of Engineering; 2011.

35. Macleod. Ergonomic Edge: Improving Safety, Quality, and Productivity. New York: John Wiley and Son; 2008.

36. Andini F. Risk factors of low back pain in workers. J Majority. 2015;4(1):12-9.

37. Kurniawidjaja LM. Teori dan Aplikasi Kesehatan Kerja. Depok: Penerbit Universitas Indonesia (UI-Press); 2015.

38. Khandan M, Maghsoudipour M, Vosoughi S, Kavousi A. Safety climate and prediction of ergonomic behavior. Int J Occup Saf Ergon. 2013;19(4):523-30. http://doi.org/10.1080/10803548.20 13.11077018 PMid:24321631

39. Nurwahyuni DR, Naeim F. Faktor yang Berhubungan Dengan Keluhan Nyeri Punggung Bawah Pada Pekerja Bongkar Muat Barang Pelabuhan Nusantara Kota Pare-Pare Tahun; 2012. Available from: http://digilib.unila.ac.id. [Last accessed on 2020 Oct 18].

40. Robbins SP, Judge TA. Organizational Behavior. $17^{\text {th }}$ ed. Boston: Pearson; 2017 